Ichoroh James ${ }^{1 \star}$, Kiambati Kellen², Mbugua Levi ${ }^{3}$, ${ }^{1}$ California Miramar University ${ }^{2}$ Karatina University

${ }^{3}$ The Technical University of Kenya

\title{
Core Competencies and Resource Allocation in the Performance of Bottled Water Industry
}

DOI: 10.7595/management.fon.2021.0040

\begin{abstract}
:
Research question: This paper examines the influence of core competencies, resource allocation and water sector standards on the performance of firms in the bottled water industry. Motivation: For firms in the bottled water industry to remain afloat, their performance against their targets needs to be assessed (Murugesan et al., 2016). Examining trends over time is essential since stakeholders and investors are concerned with enhanced performance. This study conceptualizes that the performance of firms dealing with bottled water are influenced by core competencies (Hirindu, 2017), resource allocation (Catherine \& Lee, 2017) and that there is an intervening effect of water sector standards. Idea: The idea behind this study is to model the relationship among core competencies, resource allocation and firm performance in the bottled water industry and also to examine the moderating effect of water sector standards in explaining firm performance (Ichoroh, 2021). Data: The study used quantitative cross-sectional survey design of which the population of interest comprised of 80 licensed bottled water manufacturing firms in Kenya. Open and closed ended questionnaires were administered to managers of bottled water firms. Data on demographic characteristics, firms core competencies, resource allocation and sector standards were collected. Tools: Factor Analysis was used to scale, classify, delineate patterns and enhance hypothesis testing, while structural equation modelling was applied to infer whether the survey items matched the measured constructs. Findings: The indicators of core competences had $57 \%$ variation on firm performance and increase in core competences by a factor of $0.804 \%$ led to improvement of firm performance by $1 \%$. The indicators for resource allocation had $17 \%$ variation on firm performance and the marginal effect was $1.738 \%$. The water sector standards intervening effect in the relationship between core competence and firm performance was found not to be significant but the intervening effect of water sector standards on resource allocation and firm performance was significant. Contribution: The study gives indicators of repositioning strategies in the bottled water industry and provides insights to the government on policy regulations and standards.
\end{abstract}

Key words: government intervention, interaction effect, strategic repositioning, structural model, water sector standards JEL Classification: M3, C3

\section{Introduction}

With the immense benefits of clean drinking water and public awareness of health risks, different brands of bottled water have evolved over time. With competition in the bottled water industry majorly based on price and market leadership, these firms require competitive strategies which include, among others, strategic positioning, differentiation, matching resources and cost with production (Mentzer et al., 2004). Strategic positioning may also be used by firms when they deliberately expand into new markets to achieve their set targets embedded in their objectives. Whilst decline suggests a need for change as a result of poor strategy, improvement indicate a better strategy, hence acceleration going into the future (Jalagat, 2016). The use of appropriate competitive strategies often guarantees not only a firm's survival and continuity but also the achievement of above average performance (Luliya et al., 2013). Differentiation is majorly done through pricing strategies, promotional activities and through product design. Timely and right positioning strategy can build a powerful brand image in the mind of consumers (Sair et al., 2014). However, new market entrants, 
change in attitudes and preferences by customers as well as changes in the market structures may fail to resonate to the required strategy. Under such circumstances, firms may consider strengthening their position and look for underserviced niches to occupy the space by changing the customer's perception on the product or the brand image (Blythe, 2007).

Since resource availability and multiple products positively affects firms' performance (Tharamba, 2018; Gachimu and Njuguna, 2017), there is a need for management of firms to conduct an in-depth study on determinants of strategic positioning as a driver of growth. This is necessitated in the bottled water industry by an increase in health awareness, perceived quality and safety of bottled water over non-bottled water, taste, portability, and as a replacement for carbonated soft drinks (Ichoroh, 2021). The proliferation of bottled water manufacturers in Kenya from one in 1988 to over 600 licensed manufacturers in 2016 (KEBS, 2019) has led to growth in volume, value, increase in the number of brands in the market and a sharp decline in bottled water imports. With quality standards violations being an issue of concern, there is a need of assessing core competencies, resource allocation and the intervening effect of water sector standards on the performance of firms in the bottled water industry in Kenya.

According to Chi-Jen (2017), slight changes in policy and enhanced sector standards can rapidly transform the market more especially when there are retail price reforms and subsidy programs. Lakshmi et.al. (2017) found that the overall pleasant appearance of manufacturing industries in India had a high buyers' bargaining power and low suppliers' authority, hence moderate information from new entrants. It is in this manner that substitutes posed dangers necessitating the need for positioning at the same time making firms spend colossal amounts in promotional strategies and advertisements with growing consumers' interest. On the other hand, large firms concentrate on innovate strategic marketing structuring services. Faustin and Eric (2017) found that the dominant repositioning strategies entail brand name, selectivity, reliability, attractiveness, value for money and services. In Rwanda, strong branding influenced consumer perceptions making firms produce strong attributes that influence consumers when making their choices (Gilani \& Cunningham 2017). According to Anyango and Ragui, (2014), market strategies, strategic resources and research \& development influence product performance; likewise, firms combining resources with others, enhanced market penetration of a product. Thus, firms should enter strategic alliances to ensure that their customer needs are catered for in order to enhance a product range line and penetration regardless of their economic class. Wong and Kim (2014), Kerama and Simba (2019) found that firms should adapt strategies that provide a framework aimed at coordinating the elements of the marketing mix; thus, developed strategies need to be fine-tuned by gaining experience from being close to the consumers. They concluded that competencies, differentiation, pricing and perceived quality of service were significant indicators of firm performance.

\section{Theoretical Literature of the Research}

This study was anchored on three theories, namely, organization ecology, resource dependency and organization performance theory. Organization ecology theory offers explanation on the observed fluctuation in the number of active bottled water firms at various points in their industry life cycles at different periods. It also guides new industry players on the optimal time to enter the industry and the most appropriate attractive target segment. Firms' core competencies in recruitment, training and remuneration play a vital role in the firms' survival. The risk of mortality of an organization is initially high but declines with age, however, as external support from the environment depletes, mortality hazard increases and then declines, thus the risk of failure rises with organizational age (Le Mens et al., 2011).

The Resource Dependency Theory (RDT) defines success in an organization when it maximizes its power (Pfeffer, 2005). Firms are seen as coalitions aimed at acquiring and maintaining external essential resources using their behaviour patterns and available structures. The Resource Dependency Theory assumes that firms depend on external coalitions as well as internal ones, which emanates from social interactions designed to control and influence behaviour in an environment perceived to have valuable and scarce resources essential for firms' survival. The theory also assumes that firms work with the aim of gaining control of resources to lessen their dependence on others thus posing the problem of uncertainty in resource allocation (Adam and Tyler, 2016). This study therefore opines that resource allocation is determined by its availability, adequacy, commitment, dynamicity and budget investment policy even though managers have a limited ability to create sustained competitive advantage as exemplified by the unpredicted turbulence environment. 


\section{Empirical Literature}

Mohammed (2016) opines that the quality of modern firms' human resource is anchored on well-developed employees' capabilities as a result of training. The study concluded that there existed a positive significant correlation between training \& development and employees' productivity \& performance. Hence effective training programmes should be provided to enhance knowledge and upgrade skills through carefully set development plans. Yinka (2017), reported that people were vital in organizations as they offer tenets, qualities, perspectives and attributes to the organizational human traits and life of which can be of considerable benefits in effective management of organizations. The study concluded that the selection of employees through competitive recruitment to a greater extent determines the performance of an organization. Ojeleye (2017) found a positive strong relationship between employee performance \& remuneration and recommended that employees entitlements, prompt wage payments and their participation in pay negotiations were some forms of motivation to the employees. According to Hirindu (2017), core competencies are a measurable behaviour of an individual that distinguishes performance in a given role and job. In an organization, it is the main construct of performance. The study postulated that competence capabilities and resources accelerated a firm's competitive advantage. Thus, this study hypothesizes that there exists a positive association between core competencies and firm performance in the bottled water industry in Kenya.

Catherine and Lee (2017) found that resource allocation of either financial, physical, technological or human resources is fundamental in strategic management since they support firm strategies. Lovallo, et al (2020) examined the correlation between financial resource allocation and the overall measure of firm performance. The study established a positive correlation between capital reallocation across business segments even though the relationship did not exist in extreme allocations, hence they concluded that firms would benefit from larger internal re-allocation of capital. This study therefore hypothesizes that there is a positive and strong significant relationship between resource allocation and firm performance in the bottled water industry in Kenya. Wang (2017) reported that there was a positive non-intervention policy that minimized the power of government in influencing the market leading to active innovative supply and demand equilibrium in Hong Kong markets, as compared to Singapore where activities were largely policy driven and dominated by big players. The study found evidence for the effectiveness of sector standards in enhancing technological innovation.

\section{Research Methodology}

This study used quantitative research methodology where the target population comprised 840 licensed and active bottled water manufacturing firms in Kenya in 2019. A simple random sampling procedure was adopted to select a sample of 426 firms using Njiri et al. (2021) technics of sample size determination. Closed- and open-ended questionnaires were offered to managers of the selected firms. The questionnaire sorted the background information of the respondents and sections on core competencies, resource allocation and water sector standards were included. The items were measured by Likert scale-from (1) to (5). Piloting was conducted to ascertain reliability, and the Cronbach alpha coefficient test statistic was applied as recommended by Milton, Bull and Bauman (2011) with a threshold value of 0.70 . Piloting also ensured that the degree to which data collected using the instrument in question represented the content of a particular concept (content validity) and the instrument measured the characteristic being investigated (construct validity).

\section{Study Results and Discussion}

In this study, descriptive statistics were used, likewise bivariate and factor analyses were conducted. Structural models were developed to answer the study hypothesis.

\subsection{Study descriptive statistics}

A total of 345 questionnaires were completed representing $81.4 \%$ percent response rate. Male respondents were larger in number (64.05\%) as compared to the female respondents (35.95\%). Walayet and Khana (2013) postulated that firms' risk levels tend to be lower for females' chief executives as compared to their male counterparts. Hence firm performance was influenced by the CEO gender. 
Table 1: Descriptive statistics

\begin{tabular}{|c|c|c|}
\hline Item & Percentage (\%) & Cumulative percentage (\%) \\
\hline \multicolumn{3}{|l|}{ Gender } \\
\hline Male & 64.05 & 64.05 \\
\hline Female & 35.95 & 100 \\
\hline \multicolumn{3}{|l|}{ Age in years } \\
\hline age $\leq 20$ & .6 & .6 \\
\hline $21 \leq$ age $\leq 30$ & 25.2 & 25.8 \\
\hline $31 \leq$ age $\leq 40$ & 41.2 & 67.0 \\
\hline $41 \leq$ age $\leq 50$ & 23.4 & 90.4 \\
\hline $51 \leq$ age $\leq 60$ & 9.3 & 99.7 \\
\hline age $>60$ & .3 & 100.0 \\
\hline \multicolumn{3}{|l|}{ Level of education } \\
\hline Secondary Level & 2.9 & 2.9 \\
\hline Diploma & 21.2 & 24.1 \\
\hline Undergraduate & 51.8 & 75.9 \\
\hline Graduate & 23.5 & 99.4 \\
\hline Other & .6 & 100.0 \\
\hline \multicolumn{3}{|c|}{ Length of service in years with the firm } \\
\hline Less than 5 years & 48.0 & 48.0 \\
\hline $5 \leq$ years $\leq 10$ & 38.6 & 86.6 \\
\hline $11 \leq$ years $\leq 15$ & 7.8 & 94.4 \\
\hline $16 \leq$ years $\leq 20$ & 3.6 & 98.0 \\
\hline $21 \leq$ years $\leq 25$ & 1.2 & 99.2 \\
\hline $26 \leq$ years $\leq 30$ & .2 & 99.4 \\
\hline above 30 years & .6 & 100.0 \\
\hline \multicolumn{3}{|c|}{ Number of employees working in the firm } \\
\hline Less than 10 employees & 50.72 & 50.72 \\
\hline $11 \leq$ employees $\leq 50$ & 43.19 & 93.91 \\
\hline $51 \leq$ employees $\leq 100$ & 4.058 & 97.968 \\
\hline above 100 employees & 2.032 & 100 \\
\hline \multicolumn{3}{|l|}{ Type of firm's ownership } \\
\hline Sole proprietorship & 24.85 & 24.85 \\
\hline Partnership & 12.57 & 37.42 \\
\hline Limited liability & 61.08 & 98.5 \\
\hline Corporation and Franchise & 1.5 & 100 \\
\hline
\end{tabular}

The majority of the respondents were aged $31-40$ (41.2\%), followed by $21-30$ olds (25.2\%), 41-50 old respondents $(23.4 \%), 51-60$ years old $(9.3 \%)$, and those under 20 years of age made only $0.6 \%$ of the respondents. Only one (0.3\%) respondent was above 60 years old. According to Backman and Charlie (2020), the age of operational managers is vital for young and small firms of which sole proprietorship firms with older operational managers have better survival results.

Sharon et al. (2019) and Vaz (2021) found that as managers' age progresses, firms end up posting lesser sales growth and lower investment. To the contrary, the probability of the firm's survival goes up. They found a positive relation inherent in profitability among younger managers in small firms and a negative relation among older managers in large firms. They suggested a hybrid of younger and older managers in managerial approaches. In terms of the level of education, a majority (51.8\%) were undergraduates while the fewest $(0.6 \%)$ were in the category other which denoted non-formal education as well as home based learning. According to Cornell University (2018) the level of education can be leveraged to support and enrich an individual's economic rationality in decision making. Since most of the respondents had at least a diploma, their decision-making encourages larger ownership and ensures that local needs are reflected. They include collaboration and effective consultation with stakeholders with transparent and open communication procedure at all stages of the process. Education also offers a better understanding of the background to the issue, purpose, aims as well as knowledge of interpreting findings from relevant evidence-based research. Based on the length of service in the firm, most of the respondents (48\%) had worked for a period of less than 5 years, followed by those who had worked for between 5 to 10 years (38.6\%), those who worked for $11-15$ years made up (7.8\%), workers for $16-20$ years (3.6\%), those who worked for $21-25$ years (1.2\%); only two respondents had worked for more than 30 years translating to $0.6 \%$ of the respondents. Likewise, one respondent had worked for a period $26-30$ years forming $0.2 \%$ of the respondents. The length of service was found to be correlated with the managers' experience. This can be explained by the fact that man- 
agers are administrators and provide leadership hence their skills should be diverse to achieve a successful culture and shape the future of the firm (Murugesan et al., 2016). According to Alexander et al. (2018) firms' age had significant effects on firm innovation performance, survival, financial performance and growth.

\subsection{Bivariate analysis}

The test for association between age and length of service in the bottled water firms yielded Pearson ChiSquare $\left(X^{2}=5.017, p\right.$ value of $\left.0.542>0.05\right)$. Hence the null hypothesis that age and length of service in the firm were not associated was rejected, therefore these results reviewed that gender and length of service with the firm were independent. To confirm the null hypothesis of independence between the number of employees in the firm and the number of years the firm had operated, the Pearson Chi-Square value was $\left(X^{2}=\right.$ $160.347, p$ value $<0.05)$. This led to the rejection of the null hypothesis that there is no association between the number of employees in the firm and the number of years the firm had operated. The test for association between age and gender yielded Pearson Chi-Square $\left(x^{2}=18.236, p\right.$ value equal $\left.0.003<0.05\right)$. This led to the rejection of the null hypothesis that age and gender are independent. This implied that age and gender were dependent. In fact, male managers appeared to be much older as compared to their female counterparts. Kotur and Anbazhagan (2014) investigated the influence of gender and age on workers' performance in firms and found that middle-aged workers performed better as compared to both the younger workers and their older colleagues even though the degree varied. On the other hand, female workers performed better compared to their male counterparts. They concluded that firms need to capitalize and take advantage of their employees' differences as documented in the sociology of labour. Competitive pressures among workers and current demographic trends may also induce different forms of discrimination in the organization as highly evident in the service sector (John \& James, 2006). The test for association between age and level of education yielded Pearson Chi-Square $\left(X^{2}=9.804\right.$, $p$ value of $\left.0.044<0.05\right)$. This led to the rejection of the null hypothesis that age and level of education had no association. Hence the study concluded that age and level of education were associated. In fact, males appeared to be more educated in comparison with females. The test of association between firm ownership and number of employees yielded (Pearson Chi-Square of $X^{2}=213, p$ value $<0.05$ ). This led to the rejection of the null hypothesis that there was no association between ownership and number of employees in firms. This study therefore concluded that there was an association between firm ownership and the number of employees, implying that sole proprietorship and partnership had fewer employees as compared to limited liability firms. These results confirm that limited liability firms attract a wider category of investors including the government and can mobilize more and widespread resources.

\subsection{Results from factor analysis}

Core competences variable was measured using ten 5-point Likert scale items with responses comprising very low, coded as (1), low coded (2), moderate coded (3), high coded (4) and very high was coded (5). The reliability level reported for these items was 0.916 . The KMO and Bartlett's test results for competitor awareness reported a Chi-square value of 2395.199 with $p$ value less than 0.001 . The sampling adequacy value reported was 0.917 which was higher than the required threshold of 0.50 and the Bartlett tests of sampling adequacy was less than 0.001 . The data set was thus considered suitable for factor analysis. From the ten items used to measure core competencies, one factor was extracted using Principal components analysis reporting Eigen value greater than 1.0 and accounted for $59.278 \%$ of the total variation in measuring core competencies. The study concluded that core competency can be explained by one sub theme when examining bottled water industry performance in Kenya. Hence right competencies lead to productivity and assured future growth in different ways including diversification due to different capabilities.

Resource allocation variable was exemplified using 13 items in a 5-point Likert scale measurement ranging from (1) for very low extent, (2) low extent, (3) neither high nor low extent while a code of (4) denoted high extent and (5) very high extent. The computed reliability for these items was 0.898 . The reliability test results (KMO and Bartlett's) for resource allocation reported Chi-square value of 2197.639 with $p$ value less than 0.001 . The data set was thus considered suitable for factor analysis. Three factors reported Eigen values greater than 1.0. The three factors accounted for $32.85 \%, 19.19 \%$ and $14.94 \%$ variances respectively with total variance of $66.995 \%$ explained. The three subthemes extracted were sourcing, Internal processes \& procedures and revenue. Lastly, the dependent variable firm performance was construed using twenty (20) indicators measured in a 5-point Likert scale (Ichoroh, 2021), of which the measurement values ranged from strongly agree coded as (5), agree coded (4), neutral (3), disagree (2) and (1) denoting strongly disagree. The reported reliability for these twenty items was Cronbach alpha 0.864 which exceeded the threshold value Cronbach alpha of 0.7 
(Keith, 2018). The reported KMO reliability test statistic was 0.878 (Chi-square 2912.227) and the Bartlett's test results reported $p$ value of less than 0.001 . Principal component analysis extracted four factors which had subthemes: growth in assets, staff development, profit growth and capital investment strategy.

\subsection{Measurement and structural model}

The first null hypothesis in this study was that there exists no association between core competencies and firm performance in the bottled water industry. To examine this hypothesis a structural model relating core competencies and performance of firms in the bottled water industry was fitted (Ichoroh, 2021) as is illustrated in Figure 1. The ten items used to measure core competencies were: competence based recruitment of staff (COP2), competitive remuneration (COP3), staff incentives (COP4), employees performance management (COP4b), incentives pegged on performance (COP5), staff engagement in the implementation process (COP6), employees adaptation to changes in plans (COP7), firm's help to employees to shift and pivot in response changes (COP8), firm's changes to employees management (COP9) and firm's shares with employees opportunities available for personal development (COP10). Seven of these items were retained in the measurement model. These include: competence based recruitment of staff, competitive remuneration, staff incentives, incentives pegged on performance, staff engagement in the implementation process, employees' adaptation to changes in plans and firm help to employees to shift and pivot in response changes.

Firm performance was construed using 20 items of which factor analysis retained eleven items, namely: profit growth rate (CPF2), growth in sales (CPF3), increase in employees (CPF4), returns on assets (CPF6), returns on borrowed money (CPF7), expansion in size (CPF11), quality improvement (CPF12), profit (CPF15), total assets (CPF16), number of staff (CPF17) and staff attrition (CPF18). The items eliminated were capital (CPF1), number of outlets (CPF5), customer acquisition (CPF8), market share (CPF9), delivery of products (CPF10), suppliers (CPF13), new products (CPF14), number of existing customers and customer growth (CPF 16). COP 8 was treated as the base and the regression weight for COP7 when predicting core competences was significant $(\beta=1.042, C R=13.290, P<0.05)$. The regression coefficient for COP6 when predicting core competences was significant $(\beta=1.03, C R=$ $13.235, P<.05)$. Likewise were the coefficient weight for COP5 $(\beta=1.304, C R=16.031, P<.05)$, the coefficient for COP4 $(\beta=1.458, C R=16.817, P<.05)$, the coefficient for COP3 $(\beta=1.331, C R=15.8, P<$ $.05)$ and the coefficient for COP2 $(\beta=0.916, C R=11.681, P<.05)$. Overall, the indicators of core competences had $57 \%$ variation on firm performance. The marginal effect of core competences indicated that an increase in core competences by a factor 0.801 will improve firm performance by $1 \%(\beta=$ $0.801, C R=10.435, P<.05)$. These results imply that: first, the removed items, namely, employees' performance management and sharing with employees' opportunities available for personal development do not explain competencies as earlier theorized. Secondly, competencies must be relevant to the thrust of the firm in identification of the critical areas, which includes packaging and new product development which can be achieved by having relevant recruitment, training and remuneration policies that will give the firm a market edge. Finally, financial control indirectly contributes to the success factors of the bottled water industry.

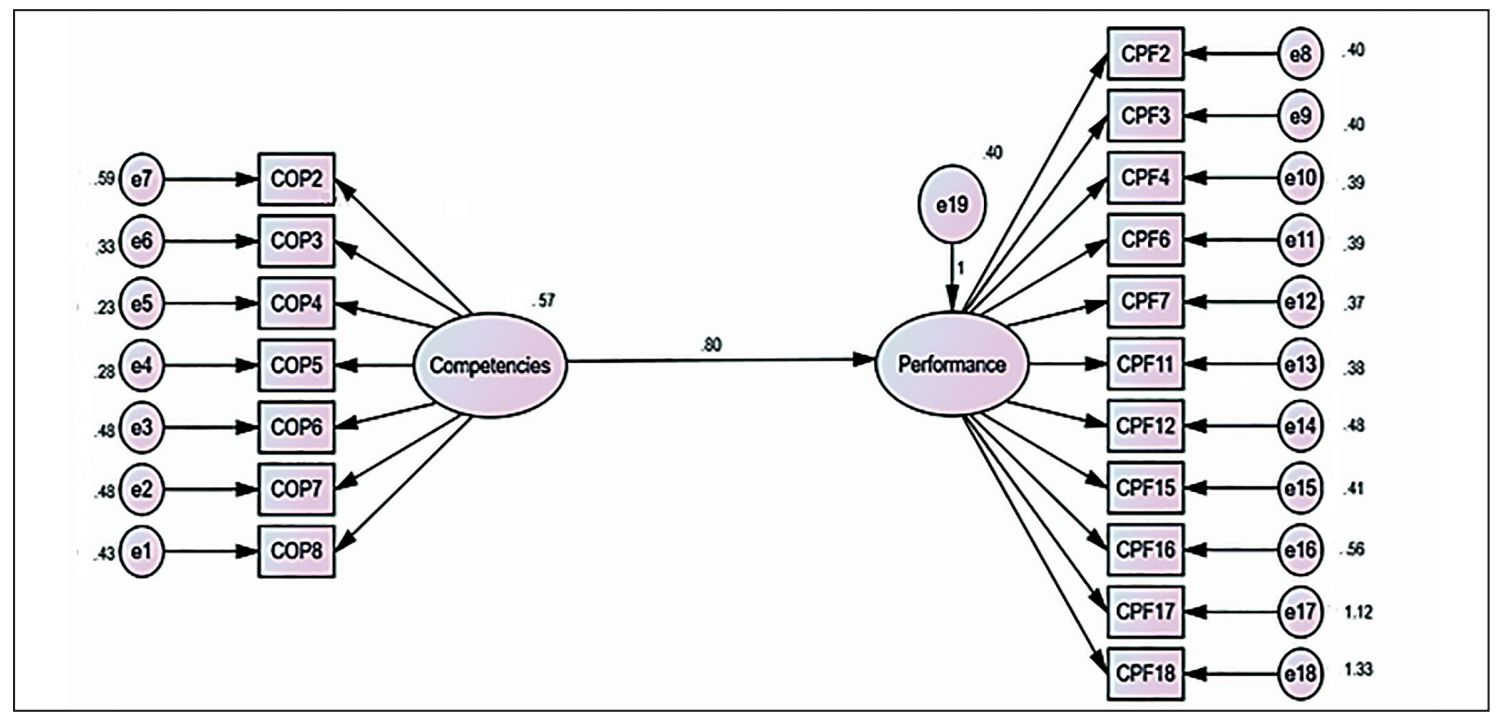

Figure 1: Structural model relating core competencies and firm performance 
To examine the hypothesis that there exists a relationship between resource allocation and firm performance in the bottled water industry in Kenya, a structural model relating to resource allocation and firm performance was developed as is illustrated in Figure 2. Resource allocation was construed using thirteen items namely: linkage between goals and budget (RAL3), sourcing of resources (RAL4), access to valuable sources of supplies (RAL5), sufficient number of full time employees (RAL6), sufficient information resources (RAL7), resources for product development (RAL8), investment in process improvement (RAL9), well defined production control (RAL10), measurable performance targets (RAL11), internal audit control (RAL12), corporate social investment (RAL13), advertisement and promotions (RAL14) and research and development (RAL15).

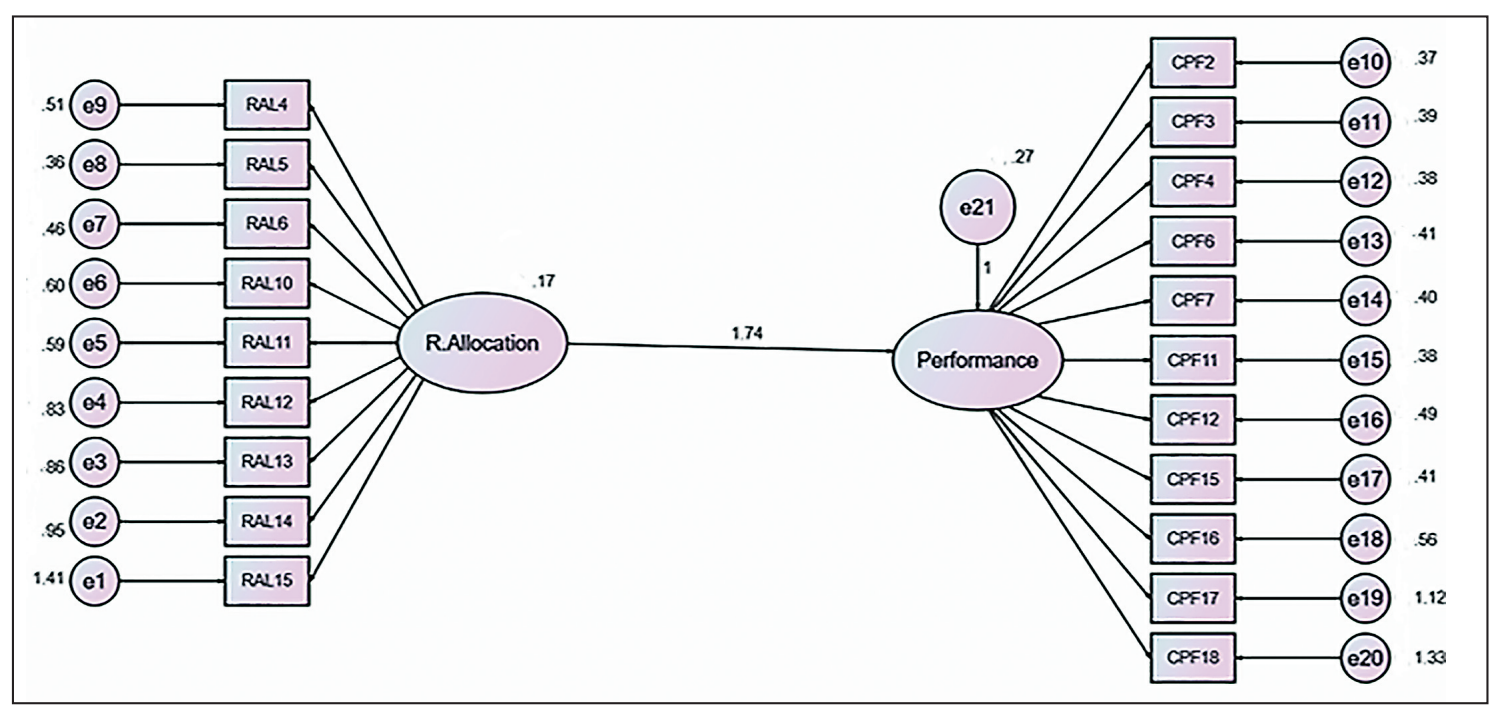

Figure 2: Fitted model relating resource allocation to firm performance

Nine items were retained by factor analysis as illustrated in Figure 2. The regression weights for the remaining items retained when predicting resource allocation treating RAL 15 (Research and Development) as the reference item were: RAL14 (advertising and promotions) $(\beta=1.885, C R=$ $5.137, P<.05)$, RAL13 (corporate social investment) $(\beta=2.176, C R=5.273, P<.05)$, RAL12 (internal audit control) $(\beta=0.754, C R=3.931, P<.05)$, RAL11 (clearly defined measurable performance targets for each department) ( $\beta=1.012, C R=4.721, P<.05$ ), RAL10 (well defined production controls) $(\beta=$ $0.989, C R=4.684, P<.05$ ), RAL6 (sufficient number of full-time employees) $(\beta=2.31, C R=5.437, P<$ $.05)$, RAL5 (access valuable sources of supply) $(\beta=1.616, C R=5.346, P<.05)$, RAL4 (policy to guide the sourcing of the resources) ( $\beta=2.441, C R=5.437, P<.05)$. The items removed related to the linkage of firm's corporate goals to financial budgets, sufficient information resources, provision of resources for product development programmes and investments in process improvement. Overall, the indicators of resource allocation had $17 \%$ variation on firm performance. The marginal effect of resource allocation was $1.74 \%$ implying that an increase in resource allocation by a factor 1.738 means that firm performance would improve by $1 \%(\beta=1.738, C R=5.276, P<.05)$. Overall, combining core competencies and resource allocation when predicting firm performance, reported that resource allocation had a positive and significant weights (Beta $=1.356, \mathrm{SE}=0.238, \mathrm{CR}=5.697, \mathrm{P}<.05$ ) while core competencies reported a positive relationship even though it was not significant (Beta $=0.130, \mathrm{SE}=0.084, \mathrm{CR}=1.544$. $P=0.123)$. This is reported in Figure 3. Net operating profit (CPF15) and total assets (CPF16) were not significant in explaining firm performance in the overall model $(P=0.124)$ and $(P=0.113)$ respectively.

These results imply that to enhance firm performance resources need to be re-allocated where there are higher returns. Control of resources and adequate staffing were found to be requisite in defining the firm's market and can be enhanced through research and development. 


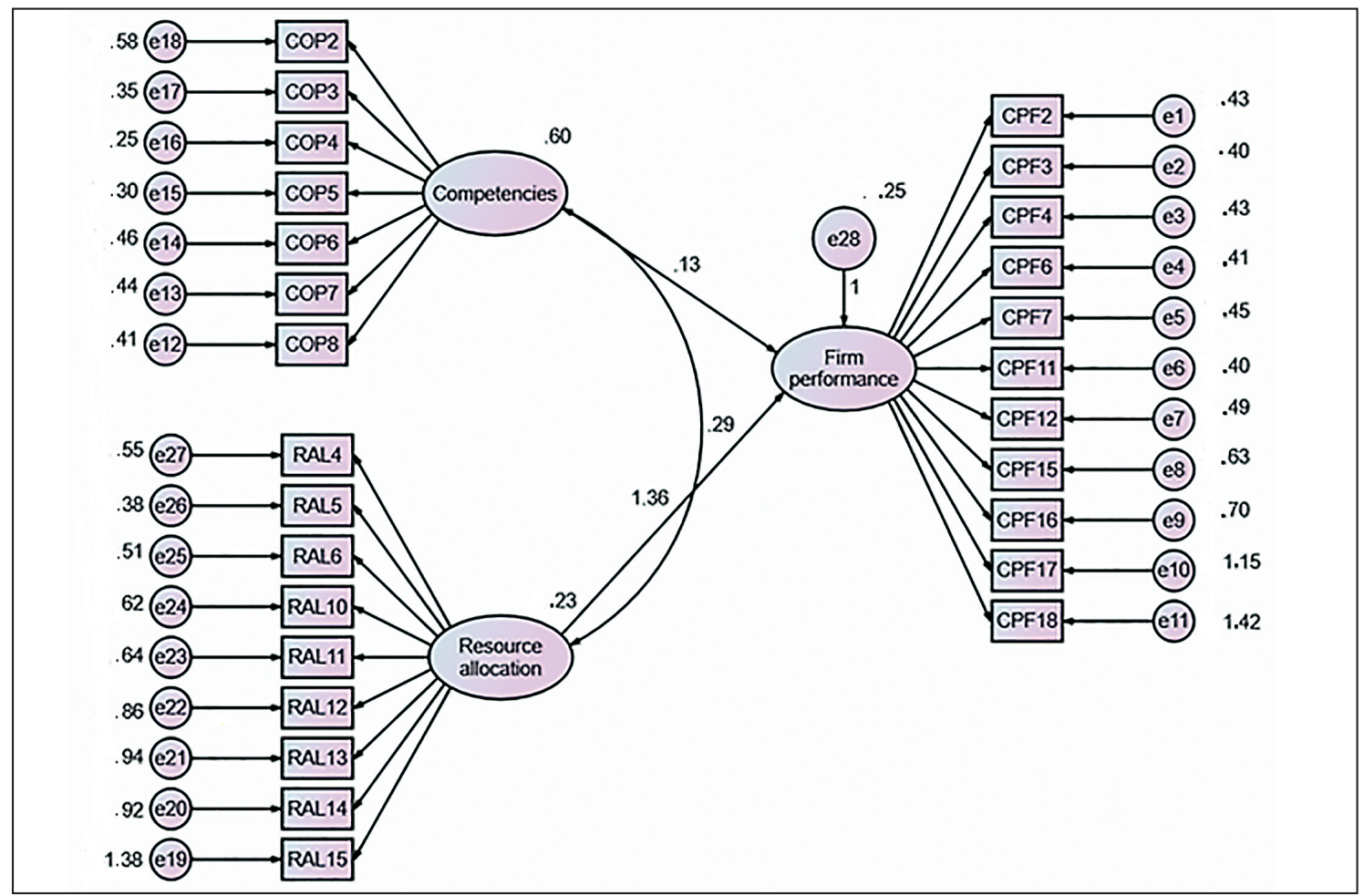

Figure 3: Structural model of core competencies, resource allocation and firm performance

Water sector standards were treated as the intervention variable in the relationship between Core Competence and bottled water industry performance in Kenya. The intervention effect was examined using the $z$ scores for core competencies, $z$ scores for water sector standards as well as the interaction effect. The regression weights and their corresponding p-values are presented in Table 2.

Table 2: Moderating effect statistics relating water sector standards to core competencies and firm performance

\begin{tabular}{|lll|cccc|}
\hline & & & Estimate & S.E. & C.R. & P \\
\hline StdZ02 & $<---$ & ZCCOMPETENCIES & .310 & .052 & 5.939 & $\star \star \star$ \\
StdZ02 & $<---$ & StdZ01 & .518 & .052 & 9.879 & $\star \star \star$ \\
StdZ02 & $<---$ & Interaction & .065 & .040 & 1.612 & .107 \\
\hline
\end{tabular}

From Table 2, the interaction term of core competency and water sector standards reported a p value of 0.107 which was higher than the reference 0.05 . The study therefore concluded that the intervening effect of water sector standards on core competencies and firm performance was statistically not significant $(p=0.107>$ 0.05). Therefore, water sector standards have no influence when explaining firm performance using core competency in the bottled water industry. These results imply that since core competencies are abilities inherent in the firm, the government has no direct influence. But the government will control the activities of the firm indirectly due to its monopoly over the source of water and quality control guidelines. This is prudent due to public health concerns and other externalities.

To test the hypothesis that water sector standards have a statistically significant effect on the relationship between resource allocation and firm performance in the bottled water industry, the $z$ scores for resource allocation were obtained along with $z$ scores for water sector standards and their interaction effect was examined. The results are presented in Table 3. 
Table 3: Moderating effect statistics modelling water sector standards, resource allocation and firm performance

\begin{tabular}{|l|cccc|}
\hline & Estimate & S.E. & C.R. & P \\
\hline Z RALLOCATION & .306 & .053 & 5.733 & $\star \star *$ \\
Z Water sector standards & .518 & .054 & 9.548 & $\star \star *$ \\
Interaction effect & .082 & .040 & 2.045 & .041 \\
\hline
\end{tabular}

As seen in Table 3, the effect of water sector standards in moderating resource allocation and firm performance was found to be statistically significant $(p=0.041<.05)$ and therefore the null hypothesis was rejected. Hence the study concluded that water sector standards influence the relationship between resource allocation and firm performance. These results imply that, to achieve set standards in the water industry, government regulations are crucial and for the firm to meet the market demand in terms of volume and quality, they require resources. Therefore, it is upon the firm to develop regulation adherence policies in line with their targets as they strategize to rightfully reposition themselves.

\section{Conclusion}

Water is unrivaled and is hard to find a substitute for it and for firms with diverse product portfolio that included bottled water customers are more likely to be loyal by associating other products with bottled water brands during purchase. Employees' quick adaptation to change, their engagement in the implementation process, remuneration and performance will explain core competencies in the performance of bottled water firms. Likewise, sourcing, revenue and internal processes \& procedures are the main determinants of resource allocation. Bringing together core competencies and resource allocation in explaining firm performance operating net profit after tax and the total assets owned by the firm are not significant predictors, thus water sector standards influence exogenously resource allocation but will not significantly influence core competencies. This study recommends further research on the impact of set regulations in the market, in terms of effectiveness, risk and cost implications. Also, since social groups behaviour in terms of market segmentation keep on changing, there is a need for research on emerging markets and product diversification.

\section{REFERENCES}

[1] Adam, C. \& Tyler, W. (2016) Resource-Dependence Theory Oxford Bibliographies DOI: 10.1093/OBO/9780199846740-0072

[2] Alexander C. Jacob R., Jackie K., \& Francesco, Q. (2018). Firm age and performance. Journal of Evolutionary Economics 28(1) DOI: 10.1007/s00191-017-0532-6

[3] Anyango, M. \& Ragui, M. (2014) The Role of Strategic Positioning on Products Performance in the Telecommunications Industry in Kenya. International Journal of Science and Research 3(10)

[4] Backman, M. \& Karlsson, C. (2020). Age of managers and employees - Firm survival, The Journal of the Economics of Ageing (15) DOI: 10.1016/j.jeoa. 2019.100215.

[5] Blythe, J (2007) Advertising creatives and brand personality: A grounded theory perspective Journal of Brand Management, 14, 284-294

[6] Catherine A. \& Lee, K. (2017). Resource Allocation and Strategy. Journal of Management (43) 8, 2411 -2420 DOI: 10.1177/0149206317729738

[7] Chi-Jen Y. (2017) Opportunities and barriers to demand response in China Resources, Conservation and Recycling, (121): 51-55 DOI: 10.1016/j.resconrec.2015.11.015

[8] Cornell University. (2018, October 5). Education improves decision-making ability, study finds. Science Daily. Retrieved July 13, 2021 from www.sciencedaily. com/releases/ 2018/10/181005111436.htm

[9] Faustin, A. \& Eric K. (2017) Positioning Strategies of Retail Firms in Ghana. Journal of African Business 18(1):1-17 DOI: 10.1080/15228916.2017.1278669

[10] Gachimu, D. G. \& Njuguna, R. (2017). Strategic positioning and financial performance of commercial banks in Kenya. International Academic Journal of Human Resource and Business Administration, 2(4): 240-255

[11] Gilani, H. \& Cunningham, L. (2017). Employer branding and its influence on employee retention: A literature review The Marketing Review 17 (2) 239-256 DOI: 10.1362/146934717X14909733966209

[12] Hirindu, K. (2017). Theorizing the Concept of Core Competencies: An Integrative Model beyond Identification. International Journal of Scientific and Research Publications (7) 2 
[13] Ichoroh, J. (2021). Consumer Orientation and Competitor Awareness on Firm Performance in the Bottled Water Industry. European Journal of Management Issues, 29(2), 83-92. DOI 10.15421/192108

[14] Jalagat, R. (2016). The Impact of Change and Change Management in Achieving Corporate Goals and Objectives: Organizational Perspective. International Journal of Science and Research (IJSR). 5. 12331239. Corpus ID: 53524715

[15] John S. H. \& James H. P. (2006) Product Market Structure and Labor Market Discrimination State University of New York Press

[16] KEBS (2019) PVoC Manual Version 9.0

[17] Keith, S. T. (2018). The Use of Cronbach's Alpha When Developing and Reporting Research Instruments in Science Education. Res Sci. Educ. 48:1273-1296 DOI 10.1007/s11165-016-9602-2

[18] Kerama, R., \& Simba, F. (2019). Effect of strategic positioning on firm performance: A survey of container freight station operators in Mombasa County, Kenya. The Strategic Journal of Business \& Change Management, 6 (2), $201-226$

[19] Kotur, B., \& Anbazhagan, S. (2014). Influence of Age and Gender on the Performance. IOSR Journal of Business and Management, 16, 97-103.

[20] Lakshmi, K., Dundigal, S. \& Vijaya, K. (2017) Marketing Strategies of Indian Automobiles Companies: A Case Study On Automobile Industry. International Journal of Mechanical Engineering and Technology 8 (8) 86-93

[21] Le Mens, G., Hannan, M., \& Pólos, L. (2011). Founding Conditions, Learning, and Organizational Life Chances: Age Dependence Revisited. Administrative Science Quarterly, 56(1), 95-126. DOI: 10.2189/asqu.2011.56.1.095

[22] Lovallo, D., Brown, A.L., Teece, D., \& Bardolet, D. (2020). Resource re allocation capabilities in internal capital markets: The value of overcoming inertia. Strategic Management Journal, Wiley Blackwell, 41(8)1365-1380 DOI: 10.1002/smj.3157

[23] Luliya, T., Sununta, S., Yuosre, B., \&, Chotchai, C (2013),"Competitive strategies and firm performance: the mediating role of performance measurement", International Journal of Productivity and Performance Management, 62 (2) 168 - 184 DOI: 10.1108/17410401311295722 [accessed Mar 19 2021].

[24] Mentzer, J., Matthew B. \& Mee-Shew C. (2004) Global market segmentation for logistics services. Industrial Marketing Management 33(1):15-20 DOI: 10.1016/j.indmarman.2003.08.005

[25] Milton, K., Bull, F. \& Bauman A. (2011) Reliability and Validity Testing of a Single-item Physical Activity Measure. British Journal of Sports Medicine; (45) DOI: 10.1136/bjsm.2009.068395

[26] Mohammed, R. \& Abulraheem. S. (2016). The Impact of Training and Development on Employees Performance and Productivity. International Journal of Management Sciences and Business Research. 5 (7) 2226-8235

[27] Murugesan, S., Jayapal, G., Vinayagamoorthi, V., Kasilingam, L. \& Sigo, M. (2016) Determinants of Firm Performance: A Subjective Model, International Journal of Social Science Studies (4) 7 DOI: 10.11114/ijsss. v4i7.1662

[28] Njiri, J. Mbugua, L. Kiambati, K. \& Mwenja, D. (2021). Physical planning and growth of private primary schools in Kenya. Journal of Management and Business Education, 4(1) DOI: 10.35564/jmbe.2021.0002

[29] Ojeleye, Y. (2017). The impact of remuneration on employees' performance (A study of Abdul Gusau Polytechnic, Talata-Mafara and State College of Education Maru, Zamfara State). Arabian Journal of Business and Management Review (Nigerian Chapter), 4(2), 34-43. DOI: 10.12816/0037554

[30] Pfeffer, J. (2005). Developing resource dependence theory: how theory is affected by its environment," in Smith, K. G. and Hitt, M. A. (eds.), Great Minds in Management: The Process of Theory Development, Oxford University Press, New York.

[31] Sair, S., Nazia, R., Ali, A., Saima, U. Muhammad, J. \& Ali, A. (2014). Which Positioning Strategy Outperforms? Science International. 26 (2) 923-932

[32] Sharon, B., Anastasiya, S.\& Rebecca, Z. (2019) CEO's Age and the Performance of Closely Held Firms. Strategic Management Journal 40(6) DOI: 10.1002/smj.3003

[33] Tharamba, T. (2018) Effect of Strategic Positioning on The Firms Performance in The Telecommunications Firms in Kenya: A Case of Safaricom Limited. Strategic Journal of Business \& Change Management (5) 2 Corpus ID: 169896603

[34] Vaz, R (2021) Firm Growth: A review of the empirical literature. Economia. 30 (2) 1-20 DOI:10.15304/rge.30.2.7190

[35] Walayet A. \& Paulo, J. (2013) Ceo gender and firm performance. Journal of Economics and Business 67 55-66. DOI: 10.1016/j.jeconbus.2013.01.003

[36] Wang, J (2017) Innovation and government intervention: A comparison of Singapore and Hong Kong Published by Elsevier B.V. An open access article under the CC BY-NC-ND license (http://creativecommons.org/licenses/BY-NC-ND/4.0/). 
[37] Wong, W. Ming-Lang, T \& Kim H. (2014) A business process management capability perspective on organisation performance. Total Quality Management and Business Excellence 25(5-6) DOI: $10.1080 / 14783363.2013 .850812$

[38] Yinka, C. O. (2017). The Impact of Remuneration on Employees' Performance: A Study of Abdul Gusau Polytechnic, Talata-Mafara and State College of Education Maru, Zamfara State. Nigerian Chapter of Arabian Journal of Business and Management Review 4(1) DOI: 10.12816/0037554

Received: 2021-03-13

Revision requested: 2021-04-12

Revised: 2021-08-29 (3 revisions)

Accepted: 2021-10-04

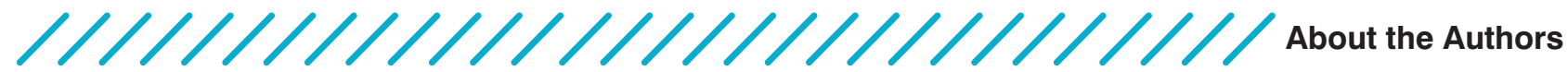

\section{James Ichoroh \\ jamesichoroh@yahoo.com}

Mr. James Ichoroh holds a BSC (honors degree) from the University of Nairobi, MBA

from the Jomo Kenyatta University of Agriculture and Technology and Post Graduate Diploma from the Melbourne university. $\mathrm{He}$ is a member of IOB and currently pursuing

Doctorate in Business Administration at California Miramar University with great interest in Beverage Technology.

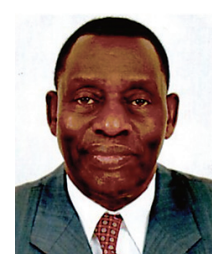

Kellen Kiambati kellenkiambati@gmail.com

Dr. Kellen Kiambati holds a Doctor of Philosophy degree in Business Administration, a Master of Business Administration and a BA (HRM) from the Kenyatta University. She is a Senior Lecturer at Karatina University and Multiple grant winning Social Scientist. Her work blends both the public service and international corporate culture and work ethics of the International Donor funded Agencies

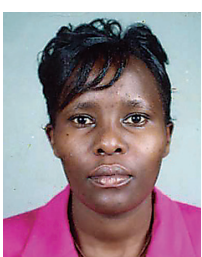

Levi N. Mbugua The Technical University of Kenya Imbugua@tukenya.ac.ke

Levi N. Mbugua holds a PhD in Applied Statistics and a MSc. in Applied Statistics. He is an associate professor in the Department of Statistics and Computational Mathematics at the Technical University of Kenya. His interests lie in Statistical Modelling, Stochastic

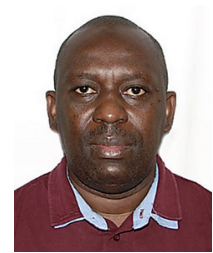
Differential Equations and Analysis of Moments of Structures. 